

\title{
ÉRTELMET AZ ÉVEKNEK - GONDOLATOK A TÁRSADALOM- ÉS HUMÁNTUDOMÁNYI GERONTOLÓGIÁRÓL
}

\author{
Dr. Simigné dr. Fenyő Sarolta
}

Kulcsszavak: értelmes elfoglaltság, gerontológia, idősödő társadalom, idősoktatás, nyugdíjkorhatár

\section{Összefoglalás}

A tanulmány egy elméleti és egy gyakorlati részből áll. Az elméleti rész a releváns szakirodalomra és a világ fejlett országainak gyakorlatára támaszkodva mutatja be az átlagéletkor növekedése következtében fellépő társadalmi problémákat és azok megoldásainak lehetőségeit. Kitér az idősödés és a nyugdíjkorhatár fogalmának tisztázására, az élethosszig tartó tanulásra, ezen belül az időskori nyelvtanulás jótékony hatásának és az idős korban hasznos, értelmes tevékenységi formáknak a bemutatására. Az empirikus rész egy, a Miskolcon 2017 novemberében megrendezett gerontológiai konferencia elött készült kérdőíves felmérés eredményeit ismerteti.

\section{Summary}

The study consists of a theoretical and a practical part. Relying on the relevant literature and the practice of the world's developed countries, the theoretical part outlines the social problems arising as a result of the increasing life expectancy. At the same time it seeks to find possibilities of solutions to these problems. It clarifies the notions of ageing and retirement age, Life Long Learning, and within this, the beneficial health effects of language learning. In addition, this part of the study introduces useful forms of activities that make sense and have meaning late in life. The empirical part describes the results of a survey made in Miskolc before the conference of gerontology in November 2017. 


\section{Bevezetés}

Antropológusok és nyelvészek már régen megállapították, hogy a környező valóság mindenki számára azonos, de nem biztos, hogy a világ különböző területein élő emberek azonosnak is látják, illetve azonos módon vélekednek róla. Ha az antropológusok elképzelése és az öregedés között párhuzamot vonunk, azt mondhatjuk, hogy az öregedés a valóságnak olyan jelensége, amelyet az emberek - még egy-egy adott országon belül és eltérő társadalmi csoportok tagjaiként is - különbözőképpen élnek meg és eltérő módon látnak. Vannak viszont tevékenységi formák, amelyek minden idős ember számára azonosak. Ilyen pl. a megszokott napi rutin megszünése és a szabadidő megsokszorozódása. Ezek következtében az idős emberek keresik a változatos, érdekes és értelmes elfoglaltságokat, amelyek színessé teszik napjaikat és értelmet adnak életüknek. A tanulmány címében azért jelenik meg az ÉRTELEM szó, mert meggyőződésünk, hogy ha értelme van annak, amivel foglalkozunk, az örömöt és elégedettséget okoz, és életünk meghosszabbításához is hozzájárulhat.

\section{Az idősödő társadalom problémáinak felismerése és kezelése a világ különböző országaiban}

A világ fejlett országaiban nő az átlagéletkor. A társadalom elöregedése gazdasági és társadalmi problémákat egyaránt felvet. A tanulmánynak ez a része azzal foglalkozik, hogy ki számít idősnek, milyen változásokat jelent az egyén életében az idősödés és a nyugdíjazás a világ különböző országaiban és Magyarországon, illetve hogy milyen szerepet vállalhat a társadalom abban, hogy a nyugdíjasok hasznosan és értelmesen töltsék el napjaikat.

\section{1/1. Idösödés, nyugdijkorhatár, öregedö társdalom}

Először arra a kérdésre keressük a választ, hogy általában ki számít idősnek. Az idős melléknév egyébként az öregedő, koros kissé szépítő változata (ÉKsz. 2003). A köztudatban az időskor kezdetét általában a nyugdíjkorhatárral hozzák kapcsolatba, mivel ez határvonalnak számít a társadalom aktív és nyugdíjas tagjai között. A köztudatban az él, hogy idős személy az, aki elérte a nyugdíjkorhatárt. Amikor 55 év volt a nyugdíjkorhatár, ez jelentette az időskor kezdetét. Jogosan merül fel a kérdés: most, hogy a nyugdíjkorhatár egyre inkább kitolódik, ez azt is jelenti-e, hogy egyre később öregszünk? Biológiai szempontból biztosan nem. Az Értelmező kéziszótár (2003) szerint az időskor „,az emberi életnek a felnőttkor és az aggkor (kb. a 60. és a 75. életév) közötti szakasza”. „Az Európai Statisztikai Hivatal (EUROSTAT) által közzétett dokumentumokban a 60 év fölöttieket tekintik 
időseknek, míg az Egészségügyi Világszervezet (WHO) és az Európai Közösség Bizottsága 2005-ös Zöld könyvében a 60. és a 65. életév között húzta meg a határvonalat: Az ENSZ idősödéssel kapcsolatos jelentéseiben régebben mindkét változatot elfogadták (de most már a 60-as határt ismerik el és használják)" (Kozányi, 2011: 100-101). Ki kell azonban emelni, hogy az öregedés egy folyamat, amelynek egyéni összetevői vannak, tehát nem lehet egyértelmü, merev határvonalat húzni az egyén középkorú és idős volta között. Az ún. öregedő társadalom kialakulásának a következő összetevői vannak: a születések számának csökkenése, a várható élettartam, továbbá az idősek számának állandó növekedése.

2015-ös adatok szerint a nyugdíjkorhatár országonként változó. Az Egyesült Államok 50 államában leghamarabb 62 és legkésőbb 65 éves korban lehet igénybe venni a nyugdíjazást. Amerikában a nyugdíjkorhatár 65 év, de előfordul, hogy valaki az előnyugdíjazás mellett dönt még akkor is, ha le kell mondania olyan társadalombiztosítási juttatásokról, amelyekre egyébként későbbi nyugdíjazás esetén jogosult lenne. A munkanélküliek is a korai nyugdíjazást választják. Mások próbálják kitolni a visszavonulás éveit, mert attól tartanak, hogy nyugdíjasként hamar felélik megtakarításaikat. Akinek viszont van munkahelye, maradhat a munkaerőpiacon. Azonban 63 éves korára a lakosságnak majdnem a fele már nem dolgozik, négy államban pedig legkésőbb 65 éves korban meg kell kezdeni a nyugdíjas éveket. Egy 2015-ös elemzés szerint a nyugdíjkorhatár Alaszkában a legmagasabb, 65 év (e-cím 1). Japánban jelenleg 60 éves kor a nyugdíjkorhatár, de az alkalmazott kérésére a munkaadó felemelheti 65 évre. Ezzel szemben Kínában a munkások 8 évvel korábban lesznek nyugdíjasok, mint az átlag amerikai. Náluk a nyugdíjkorhatár 55 év, de itt is tervezik ennek emelését. Az Egyesült Arab Emirátusban az alkalmazottak számára a nyugdíjkorhatár 49 év, míg - másik végletként - Norvégiában 67 év. Ki kell emelni, hogy a világ valamennyi fejlett országában tervezik a nyugdíjkorhatár felemelését. A tervek szerint Dániában 2022-ben, Franciaországban 2023-ban, Németországban 2029-ben szintén 67 éves korukig kell majd az embereknek dolgozni (e-cím 2). Annak pedig, aki ma az Egyesült Királyságban tízen - vagy huszonéves, arra kell számítania, hogy 70 éves koráig fog dolgozni (e-cím 3).

A lakosság idősödése várhatóan jelentősen befolyásolja majd az egészségügyi szolgáltatás megszervezését. Fontos, hogy az akut betegségekről a hangsúly átkerül a krónikus betegségekre, egyre nagyobb lesz a hiány az egészségügyben dolgozókból, elsősorban ápolókból. Az orvosi kezelések megváltoznak: egyszeri beavatkozás helyett folyamatos kezelésre lesz szükség pl. az Alzheimer-kór, a szívelégtelenség és a csontritkulás kezelése esetén. Megváltozik a kezelések célja: a betegekkel azt kell megtanítani, hogyan 
lehet együtt élni azokkal a betegségekkel, amelyek teljesen már nem gyógyíthatók. Mivel a krónikus betegségek gyakran valamilyen fogyatékossággal is együtt járnak, a hosszú távú szolgáltatások az idősotthonokban, a nappali ellátásban egyre fontosabbak lesznek (e-cím 4).

Az elörejelzések szerint 2050-re Afrika kivételével a világ minden részén többen lesznek az idős emberek, mint a gyermekek. A fejlett országokban a 85 évesek vagy a 85 évesnél idősebbek száma egyre inkább növekedni fog. Persze, a népesség elöregedésére úgy kell tekintenünk, mint kétélü kardra. Egyrészt a társadalom nagykorúvá válását jelzi, azt, hogy a több évtizedes befektetések, reformok és fejlesztések (az orvostudomány és az orvoslás fejlődése) megteremtették a hosszú élet feltételeit. Az orvosok olyan életeket mentettek meg, amelyeket korábban elveszítettek volna. A kard másik éle pedig azt mutatja, hogy ezt a szép kort megért emberek az állam számára egyre több költséget jelentenek (Tam, 2012).

\section{1/2 Élethosszig tartó tanulás}

Mivel az agyban lejátszódó kognitív folyamatoknak köszönhetően a tanulás az egészség megőrzésében és az élet meghosszabbításában egyaránt fontos szerepet játszik, a gerontológia társadalmi aspektusai közül prioritásként ezzel foglalkozunk. A fejlett országokban különböző programok léteznek az idős korban való tanulás és a tanulás jövőjének biztosítására. Az Egyesült Királyságban pl. az élethosszig tartó tanulásnak a következő 4 fázisát különböztetik meg, amelyeknek része az időskori tanulás is: 18-25, 25-50, 50-75 és 75 éven felüliek csoportját, és meghatározzák, melyik csoport tanulását milyen pénzösszeggel támogatja a kormány. Legtöbbet a legfiatalabbak és legkevesebbet a legidősebbek kapnak. Kutatók fáradoznak azon, hogy kidolgozzák az élethosszig tartó tanulás programját, újragondolják a tanuláshoz szükséges kulturális és társadalmi értékeket és kiszámolják, hogy az új perspektívák megnyitásához (pl. digitális technológia, egészség) milyen anyagi befektetések szükségesek. Kimutatták, hogy a demográfiai változás következtében szükséges a támogatás sokkal igazságosabb elosztása és annak tudatosítása, hogy a tanulás valóban nagyon sokat segíthet abban, hogy az idős emberek aktívak és egészségesek maradjanak. Az Európai Bizottság pl. az idősödő lakosság igényeire reagálva hozta létre a LARA (Learning A Response to Ageing) projektet, amelynek célja, hogy az idősoktatásra tanárokat képezzen ki, és a program olyan oktatást biztosítson, amely az idősek igényeinek megfelel (Swindell, 2012: 35-37). Az időskori tanulást ugyanis számos tényező nehezíti. Csökken az érdeklődés, az alkalmazkodóképesség, romlanak a testi és szellemi adottságok. „Megfelelő idősoktatási programokkal azonban ezek a hátrányok sikeresen 
kiküszöbölhetők vagy csökkenthetők. Idős korban a motoros vagy szenzomotoros tanulással szemben előtérbe helyeződik a verbális vagy szociális tanulás” (Bajusz, 2008: 71). Az időskori tanulásban kitüntetett szerepet tölt be a nyelvtanulás, amely az agy frissítését, karbantartását szolgálja, „hiszen mai tudásunk szerint ez olyan veszélyek csökkentésére is jó, mint akár az Alzheimer-kór" (Csetneki, 2017: 21). Erre a következtetésre azt követően jutottak a kutatók, hogy „kétnyelvü beszélőket vizsgáltak, akik a fenyegető kórral szemben ellenállóbbnak bizonyultak" (i. m. 21-22). Ellen Byalistok, a Torontói York Egyetem kutatója pedig arra mutatott rá, hogy az életkorral a nyelvtanulás célja is megváltozik. Álláspontja szerint „Aki 40 vagy 60 éves fejjel még nekivág egy új nyelv megtanulásának, abból ugyan aligha lesz már kétnyelvü ember, ám önmagában a tanulás is aktivizálja az agyat. Ez pedig olyan, mintha olajozná az agy motorját” (e-cím 5).

Az Egyesült Államokban 1999-ben 16 vezető kutató részvételével multidiszciplináris, több kutatási területet is érintő tanulmány készült (a gerontológia, a neurobiológia, $\mathrm{s}$ neuropszichológia, a szociológia, a genetika, az epidemológia és más tudományterületek bevonásával), amelyben kidolgozták a sikeres öregedés modelljét (Rowe és Kahn, 1999). A modellben kiemelt szerepet kap két, az aktív élethez szükséges cselekvésforma, a közösségi hálózatok fenntartása és az érdekes dolgokkal való foglalkozás. A közösséghez való tartozás pl. magába foglalja, hogy az embernek, mint társas lénynek legyenek olyan szaktudással rendelkező barátai, akikhez akkor fordulhat, ha nehézségei, problémái adódnak. A társadalmi hálózatok szorosan kapcsolódnak az egészséghez és a jó közérzethez. Egy 1988-as tanulmány azt mutatta ki, hogy ha a szociális háló szétesik, ha a társadalmi kapcsolatok megszünnek, ez ugyanolyan egészségi problémákat okozhat, mint a fiatalkori dohányzás. Az időskori tanulás résztvevői számára rendkívül fontos, hogy olyan közösségi hálózat résztvevői legyenek, amelyen belül hasonlóan gondolkodó kollégákkal találkoznak. Az érdekes tevékenységek között a szakirodalom az önkéntes munkát emeli ki, amely népszerü az idősek körében, és hasznos azok számára is, akik vállalják, és azok számára is, akik annak kedvezményezettjei. Az önkéntesek azt állítják, hogy az ösztönző környezet és a rendszeres, céltudatos, értelemmel bíró cselekvés szintén hozzájárul a jobb egészségi állapothoz és a hosszú élethez.

Kínában az idősek tisztelete Konfucius tanaira vezethető vissza. Az idős embereket a múltban kifejtett tevékenységük, szakértelmük, bölcsességük és tapasztalataik alapján tisztelik, amelyek a család és a tágabb értelemben vett társadalom számára egyaránt hasznosak. Kínában az élethosszig tartó tanulás az 1980-as években, a Kulturális Forradalmat 
követően erősödött meg. Az országban 2012-ben számos Harmadik Kor Egyeteme müködött, és az intézményeknek több mint 4.3 millió öreg diákja volt. Kezdetben a társas összejövetelekre (éneklés, tánc, társasági kapcsolatok) koncentráltak, később az idősek számára számítógépes kurzusokat, angol nyelvtanfolyamokat szerveztek és olyan tárgyakat is tanítottak, mint pl. a betegségek diagnosztizálása és megelőzése (Swindell, 2012).

\section{1/3. Magyarországi vonatkozások}

Külföldön, különösen a fejlett országokban gazdag hagyománya van annak a tevékenységnek, amelyet mi a társadalom- és humántudományi gerontológia tárgykörébe sorolunk. Természetesen még sok elméleti és gyakorlati ismeret és tennivaló szükséges ahhoz, hogy a nyugati országokhoz felzárkózzunk. Jelentős előrelépés, hogy Magyarországon a gerontológia nemcsak tantárgyként szerepel az egészségtudományi és társadalomtudományi egyetemek és főiskolák képzési struktúrájában, hanem kiemelt kutatási témaként is. Egészségtudományi intézetekben már nálunk is indítanak pl. szociális gerontológia szakirányú továbbképzést ápolók, védőnők és pedagógus végzettséggel rendelkezők számára. Rendeznek országos konferenciákat, amelyek témája az idősödő generáció problémáival való törődés. A Zsigmond Király Főiskolán pl. 2011 óta Gerontoedukációs Kutatóközpont müködik, negyedévente folyóiratot jelentetnek meg. A 2011-es 2. számban olvashatunk pl. az idősekkel kapcsolatos negatív attitüdök leküzdésének lehetőségeiről, az idősebb korosztályok tanulási sajátosságairól, az érintett intézmények együttmüködéséről és a kommunikációval kapcsolatos tevékenységek koordinálásának szükségességéröl. Örvendetes tény, hogy az országos „hálózatban” Miskolc előkelő helyen szerepel, hiszen az országban elsőként itt alakult meg 2010-ben és azóta is eredményesen müködik a Harmadik Kor Egyeteme Miskolc Alapítvány, amely számos lehetőséget és tartalmas programot biztosít az idősödő emberek számára. Hírlevelük rendszeresen nyújt információt a különböző programokról és nagy népszerüségnek örvend a Szépkorúak akadémiája is. 2017 nyarán a paletta ismét bővült. A Magyar Tudományos Akadémia Miskolci Területi Bizottságának égisze alatt megalakult a Társadalom- és humántudományi gerontológia munkabizottság, amely első tudományos konferenciáját 2017. november 8-án tartotta. Célja az volt, hogy átfogó képet adjon az idősödés tudományáról, annak multi- és interdiszciplináris jellegéről. „A konferencián gerontológus, filozófus, szociológus, pszichológus és andragógus szakemberek, továbbá orvosok, jogászok és nyelvészek, valamint analitikus kémiával, egészség- és táplálkozástudománnyal foglalkozó kutatók tartottak előadásokat”, amelyeket nagy érdeklődés kísért (ecím 6). Természetesen a tudományos ismeretek, az előadások mellett az aktív időskor 
megéléséhez gyakorlati tapasztalatok is szükségesek, amelyekre egyrészt személyes beszélgetések és interjúk, másrészt kérdőívre adott válaszok során derül fény.

\section{2) A kérdőívek kiértékelése}

A konferenciát megelőzően kérdőíves felmérést készítettem, amelynek célja annak kiderítése volt, hogy egyáltalán nyitottak-e az emberek arra, hogy nyugdíjas napjaikról beszéljenek; el akarják-e mondani, ki hogyan élte meg a nyugdíjba vonulást, hogyan változtak meg a körülményei, milyen tervei voltak a nyugdíjas évekre vonatkozóan, és azokból mit tudott megvalósítani. A kérdések megfogalmazásakor arra koncentráltam, hogy kiderüljön, a megkérdezetteknek milyen tevékenység jelentett hasznos elfoglaltságot, tulajdonképpen mi adott értelmet az életüknek. A kérdések összeállítását és kiértékelését azért tartottam fontosnak, hogy kiderítsem, a válaszadók által megfogalmazott gondolatok milyen azonosságokat és különbözőségeket mutatnak a szakirodalmi vonatkozásokkal. A tizenkét kérdést tartalmazó kérdőíveket összesen 23 személy, 17 nő és 6 férfi töltötte ki. Közülük 4 középfokú, míg 19 felsőfokú végzettségü. A továbbiakban csak a fontosabb kérdéseket idézzük.

\section{Várta-e a nyugdíjas éveket?}

Erre a kérdésre 19 fö igennel, míg 3 fő nemmel válaszolt. A tipikus az igen válasz volt. A nyugdíjba vonulással kapcsolatban két válaszadó szavait idézem, akik az alábbi gondolatokat fogalmazták meg:

\section{Aki várta: középiskolai osztálytársam, P. Mária}

Idős édesapja gondozása és az unokák felügyeletének szükségessége miatt várta a nyugdíjas éveket. Közben maguktól jöttek az újabb feladatok, „és ha jönnek, akkor azokat el kell fogadni”. Pl. a következőket: egyházpénztár vezetése, kerti munka, virágok gondozása, utazás az unokákkal, nyugdíjas klub létrehozása, összejövetelek szervezése (heti 1 alkalommal), a falu rendezvényein való részvétel, énekkar, kórustalálkozók Magyarországon és Szlovákiában. „Szeretettel és érdeklődéssel vesszük egymást közre, az idős embereknek az a legfontosabb, hogy meghallgassák őket: ... Egyáltalán nem szünt meg a kapcsolatom a volt kollégáimmal, még mindig küldött vagyok a Takarékszövetkezetnél. Baráti kapcsolatban is vagyunk. ... Új barátok nem kellenek, hiszen falun mindenki a barátom”. „Szerintem lehet nyugdíjasként is új tevékenységbe fogni, csak kevesebb energiát igényeljen, mint az aktív munkás években. ... Nyugdíjas korban is kellenek olyan feladatok, amelyek kihívást jelentenek, amelyekkel mások javát szolgáljuk és amelyek értelmet adnak a mindennapoknak". 


\section{Aki nem várta: H. G-né dr. D. Mária}

aki orosz-magyar szakot végzett és aktív éveiben föiskolai tanárként tevékenykedett, többek között tananyagokat és tankönyveket írt, nyelvoktatással és orosz irodalommal kapcsolatos tudományos kutatásokat folytatott. Nyugdíjba vonulásáról H. D. Mária néven a következőket írta le Keresztutak címü könyvében:

„Változatosan viharos, érdekes és izgalmas harminc éves tanári múlt után vonultam nyugdíjba (Jaj, bocsánat, máris helyesbítek: dehogyis vonultam! Küldtek! A történelem ugyanis megszüntette az egyik szakomat. Akár mondhatnám úgy is: Kiment a divatból! 1989 tájékán.) Ijedtemben el is végeztem gyorstalpalón két tanfolyamot: a talpmasszírozást és az idegenvezetést Esztergom körzetére és a pilisi romokra érvényesen. Gondoltam: jól jöhet még a nyugdíjas kenyérke - a kilencezer forintos nyugdíj mellé - egy kis kalácsra való ...” (2008: 53).

Kolléganőnk nyugdíjasként a mai napig rendkívül szerteágazó tevékenységet folytat, könyveket és tanulmányokat ír, hazai és külföldi konferenciákon előadásokat tart, közben kamatoztatja kulináris tehetségét is. Ételreceptekkel is nyert pályázatokat, 1997-ben szóhasználatát idézve -,,kertészkonyhás receptjei” (a retekleves és a kelkáposztás csirke) alapján lexikoncikként bekerült a szekszárdi Babits Kiadó „Ki kicsoda a magyar mezőgazdaságban" címü kötetébe. Marika jelenleg 82 éves, rendszeresen publikál a Muravidék Baráti Kör folyóiratainak hasábjain és szerkesztője az évente négy alkalommal megjelenő Esztergom és vidéke folyóiratnak. A mai napig ilyen és hasonló, egyrészt szakterületéhez, másrészt hobbiszinten müvelt elfoglaltságokhoz kapcsolódó tevékenységek adnak értelmet az életének.

\section{Tudott-e mit kezdeni a szabad idejével?}

\section{Tervezte-e elöre, hogy mivel fog foglalkozni, ha nyugdijas lesz?}

20 fő jól érezte magát a bőrében, amikor már nem kellett dolgoznia, míg 3 nem vagy kevésbé jól. Aki nem tudott mit kezdeni a szabad idejével, az tanulásba kezdett (3 fö). Többségük tudatosan készült a nyugdíjas évekre, és eltervezte, mivel szeretne majd foglalkozni, és több válaszadó számára adódtak új feladatok.

\section{Amikor nyugdíjba ment, teljesen megszünt-e a korábbi munkahellyel /a kollégákkal való kapcsolata?}

\section{5. Ön szerint lehet-e/kell-e nyugdíjasként teljesen új tevékenységbe fogni?}

Majdnem mindenki továbbra is tartotta a kapcsolatot a kollégáival, mindössze 3 fó gondolt arra, hogy új barátokat kellene keresnie. A felsőfokú végzettséggel rendelkezők folytatták 
korábbi szabadidős, vagy a munkájukhoz kapcsolódó, vagy pedig tudományos tevékenységüket, míg 4 fő nyugdíjasként kezdett számára teljesen új tevékenységbe.

6. Látja-e értelmét az időskori tanulásnak, ezen belül pl. egy új nyelv megtanulásának?

Erre a kérdésre a válaszadók egyharmada kitérő, illetve nemleges választ adott. Pl.:

Látna benne fantáziát, de nem biztos, hogy beleférne az életébe, és az sem, hogy ki tudná fizetni az órákat. Franciát/németet tanulna, családi indíttatásból. Nem tudna már idegen nyelvet megtanulni (ffi). Nem tud megtanulni egyetlen nyelvet sem. Szeretne angolt tanulni, de ez nem megy. Lenne értelme, de nem túl intenzíven tanulni egy nyelvet. Általában van értelme az időskori tanulásnak, de nyelveket már nem tanulna. Mivel nyugdíj mellett több helyen is dolgozik, mert nagyon kevés a nyugdíja, nem lenne ideje rá. 6 fó egyáltalán nem tartja magát alkalmasnak a nyelvtanulásra.

\section{Igenlö válaszok:}

Igen, kell az új tevékenység. Van értelme az időskori tanulásnak, olaszt/spanyolt szívesen tanulna. Lehet idős korban is tanulni, a tanulásnak mindig van értelme, föleg azért, hogy az agy müködésben legyen. Óriási sikerélmény lehet. Vannak, akik korábbi nyelvtudásukat frissítenék fel, van, aki nyelvészeti indíttatásból tanul érdekes nyelveket, pl. kínait, de a grúz is érdekli, mások külföldön élő családtagok kedvéért tanulnák meg a célország nyelvét legalább alapszinten.

\section{Mi volt a legjobb, illetve a legrosszabb számára, amikor már nem kellett dolgozni mennie?}

5 fő válaszolta azt, hogy kevesebb lett a jövedelme, egy fő viszont éppen azt értékelte, hogy rendszeresen van jövedelme. További - igencsak szerteágazó - válaszok:

\section{A legjobb az volt, hogy .....}

Azt csinálhatok, amihez kedvem van; megszünt a stressz, ki tudtam pihenni magam; jutott időm olyan szórakozásokra, amelyekre korábban nem, pl. hangverseny, operaklub, sport, fürdő, olvasás; több időt tölthetek a családdal, barátokkal; saját időbeosztásom és érdeklödési köröm szerint élhetek; 4 fö megkönnyebbülést érzett, mert nem kellett korán felkelni; több a szabadidő, volt idő elvégezni az elmaradt feladatokat; Jó volt a szabadság érzése. 


\section{A legrosszabb az volt, hogy .....}

már nem nekem csengetnek be az iskolában.; kevesebb a pénz; alacsonyabb az életszínvonal; költözködés miatt megszakadt a kapcsolata a kollégákkal; az a tudat, hogy elértem a nyugdíjas kort; nem tudom, mit hasznosíthatnék még a tudásomból, az évek során felgyült anyagokból, könyvtáram könyveiből; mivel kevesebb lett a pénzem, kevesebbet tudtam fordítani vitaminokra, táplálék kiegészítőkre; nyugdíjas kollégáim közül, akikkel korábban tartottam a kapcsolatot, sokan már nem élnek, a sporttársakkal máig is tartom a kapcsolatot; vártam a nyugdíjas éveket, de továbbra is dolgoznom kell. Egy személy azt írta, hogy semmi rossz nem volt benne.

\section{Lesz-e szüksége új barátokra?}

3 fő adott igenlő választ. A többiek vagy volt osztálytársaikkal, volt kollégákkal, illetve sporttársakkal tartják a kapcsolatot, vagy családtagjaikkal foglalkoznak többet.

\section{Mi szükséges a kiegyensúlyozott élethez?}

Fontos az aktivitás és a nyitottság mindenre, ami új; jó feleség és család; család, gyerekek, unokák; környezetem boldogulása; legyenek rövid és hosszú távú terveink, és igyekezzünk azokat megvalósítani; új tevékenység, fontos, hogy a lehető legjobbat hozzuk ki magunkból; az agy frissen tartása, pl. rejtvényfejtéssel; harmóniában lenni önmagunkkal és a külvilággal.

\section{Milyen tervei vannak a jövöre vonatkozóan?}

Nincsenek terveim, a mának élek és örülök a holnapnak; minőségi időtöltés az unokákkal, tanítgatni őket; utazgatás; olyan témákkal is szeretnék foglalkozni, olyan könyveket szeretnék elolvasni, amelyekre munka mellett nem volt időm; hobbi, utazás, konyhamüvészet.

Utolsó feladatként a válaszadóknak fontossági sorrendbe kellett rendezniük tizenkét fogalmat, ill. cselekvésformát. Első és legfontosabb dolognak egy férfi válaszadó kivételével mindenki az egészséget jelölte meg azzal az indokkal, hogy ha egészség van, akkor minden van. Igen előkelő helyet kaptak még: környezete, gyermekei boldogulása; anyagi biztonság; illetve egy válaszadónál a társasági élet. 


\section{Összegzés, kitekintés}

Ahhoz, hogy a társadalom- és humántudományi gerontológia erős interdiszciplínává váljon, és hogy az idősek számára tudományosan is megalapozott és hatékony segítséget tudjon nyújtani, szükség van egyrészt a már említett tudományos diszciplínák képviselőinek összefogására, további konferenciák rendezésére, ismeretterjesztésre, tevékenységük összehangolására és új ismeretek, tapasztalatok gyüjtésére. Másrészt szükség lenne nagyobb volumenű felmérésekre, amelyek alapján minél több idős személyt lehetne bevonni a kutatásba, és ennek kapcsán a közösségi programokba. Azok az ismeretek, amelyeket személyes beszélgetések, kérdőíves felmérések és interjúk alkalmával szerezhetünk, azt bizonyítják, hogy az idős emberek szeretnének nyugdíjas éveik alatt is tartalmas életet élni, értelmes dolgokkal foglalkozni. Arra vonatkozóan, hogy ki mit tart értelmes elfoglaltságnak, kaptunk hasonló elképzelésekre és nagyon eltérőekre vonatkozó válaszokat is. Ez azt bizonyítja, hogy a megkérdezett 23 személyt a sokféleség jellemzi, aminek következtében nyugdíjas éveikről hasonló terveik voltak és vannak, ugyanakkor azok megvalósításáról nem mindig azonos módon gondolkodnak. A jövőben fontos lenne a tanulásra, ezen belül az agy frissen tartását biztosító nyelvtanulás fontosságára felhívni a figyelmüket. A Társadalom- és humántudományi gerontológia munkabizottság azon tagjai, akik a bölcsészettudományokat müvelik, az időskori tanuláshoz kapcsolódó tevékenységgel tudnának „értelmet adni az éveknek". Részt tudnának venni az élethosszig tartó tanulás biztosításában és a nyelvoktatásban is. Meg tudnák győzni a nyelvet tanulni nem akarókat is arról, hogy idős korban mások a tanulási célok, hogy ezek a célok az agy frissen tartását és a betegségek elkerülését segítik, ezáltal a hosszabb életet biztosíthatják. 


\section{IRODALOM}

1. Bajusz Klára (2008): Az időskori tanulás. Új Pedagógiai Szemle, 58. évf., 3. szám, 69-73.

2. Boulton-Lewis, Gillian - Tam, Maureen (eds.) (2012): Active Ageing, Acitve Learning.

3. Springer, Dordrecht Heidelberg-London-NewYork .

4. Csetneki Sándorné Bodnár Ildikó (2017): Kulcsszavak: bátorság, önállóság, szorgalom.

5. Gondolatok az érettebb korban történő nyelvtanulásról. In: Alkalmazott Nyelvészeti

6. Közlemények - Interdiszciplináris tanulmányok. Miskolci Egyetemi Kiadó, Miskolc. XI. évf. 1. szám. 2016. 20-28.

7. H. Dobos Mária (2008): Keresztutak. Muravidék Baráti Kör Kulturális Egyesület, Pilisvörösvár.

8. Jászberényi József (szerk.) (2011/2): Gerontoedukáció. Zsigmond Király Főiskola, Budapest. 9. évf. 2. szám.

9. Juhász József, Szőke István, O. Nagy Gábor, Kovalovszky Miklós (szerk.) (2003): Magyar értelmező kéziszótár. Akadémiai Kiadó, Budapest.

10. Kozányi Lili (2011): Az időskor lehetőségei. In: Jászberényi József (szerk.) Gerontoedukáció. A Zsigmond Király Föiskola Gerontoedukációs Kutatóközpontjának negyedéves folyóirata 2011/2. I. éfv. 2. sz. 100-120.

11. Rowe J. - Kahn, R. 1999. Successful aging. Random House, New York.

12. Schwindell, Rick (2012): Successful Ageing and International Approaches to Later-Life

13. Learning. In: Boulton-Lewis, Gillian - Tam, Maureen (Eds.) 2012. Active Ageing, Acitve Learning. Springe, Dordrecht-Heidelberg-London-New York. pp. 35-66.

14. Tam, Maureen (2012): Active Ageing, Active Learning: Elder Learning in Hong Kong. In:

15. Boulton-Lewis, Gillian - Tam, Maureen (Eds.) 2012. In: Boulton-Lewis, Gillian 16. Tam, Maureen (Eds.) 2012. Active Ageing, Acitve Learning. Springer, Dordrecht17. Heidelberg-London-New York. pp. 163-164. 


\section{Internetes hivatkozások}

1 https://smartasset.com/retorement/average-retirement-age-in-every state 2016. (Letöltés dátuma: 2017. 09. 26).

2 http://en.wikipedia.org/wiki/ Retiremtnt_age (Letöltés dátuma: 2017. 09. 27.)

3 http://www.ageuk.org.uk/money-matters/pensions/changes-to-state-pension-age/ (Letöltés dátuma: 2017. 09. 27.)

4 https://academic.oup.com/ije/article/31/4/776/630256/Population-ageing-in-theUnited-States-of America https://academic oup.com/ije/article /31/4/776/630256/ Population-ageing-in-the-United-States-of-America (Letöltés dátuma: 2017. 11. 22.)

5 http://hvg.hu/plazs/20110207_nyelvtudassa_alzheimer_ellen-, (Letöltés dátuma: 2017. 11. 23.)

6 http://mta.hu/data/dokumentumok/Magyar\%20Tudomany\%20Unnepe/2017/MTU_20 17_ME_BTK.pd (Letöltés dátuma: 2017.10.12.)

\section{Dr. Simigné dr. Fenyő Sarolta} habilitált egyetemi docens Nyíregyházi Egyetem, Nyelv-és Irodalomtudományi Intézet Angol nyelv és Kultúra Intézeti Tanszék 4400 Nyíregyháza, Sóstói út 31/b. e-mail: sarolta.simigne@gmail.com 